\title{
Policy on Planning and Promotion of Development of Supporting Industries for Vietnam
}

\author{
NGUYẼ̃N TRỌNG HOÀI \\ Associate Professor, Doctor of Philosophy, UEH \\ email: hoaianh@ueh.edu.vn \\ HUỲNH THANH ĐIỀN \\ Doctor of Philosophy, Corporation 28 under Ministry of National Defense \\ email: thanhdien82@yahoo.com
}

\begin{abstract}
This research aims at analyzing aspects determining supporting industries (SIs) to serve the task of planning and developing such industries. Analyses show that Vietnamese SIs are very small and unable to help the manufacturing sector increase its added value and join the global value chain. The results find the following culprits: the plan and policies on SI development are not compatible with main trends of market specialization and global value chain; chain of domestic industrial production is till lacking; and inter-industry cooperation is poor. Policy recommendations, therefore, are as follows: establishing the exact list of SIs that help increase the added value of local industrial production and integrate into the global value chain; and planning space, time, track, and methods needed for carrying out such policies. Besides the development plan, the paper also offers suggestions about policies to promote SIs, such as legal infrastructure for SI development, design of a value chain for SIs, building of clusters of SIs, and mechanism for promoting SI development.
\end{abstract}

Keywords: supporting industries, planning policy 


\section{INTRODUCTION}

Industrialization is a factor in the modernizing process of the production technologies, and industrial structure from a lower to higher levels (Li, 1997; Ohno, 2006). The industrialization is considered successful when the production structure moves from assembling or doing subcontracts (with huge volumes of imported raw materials) to integrating actively into the global value chain with SIs developed to reduce imported raw materials (Mori, 2005; Ohno, 2007). Vietnam is trying to accumulate technologies to move from simple industries under guidance of foreign companies to a highly-internalized industries that can join the global value chain, and it therefore should make plan to develop SIs to serve its effort.

This paper aims at discussing the plan to develop SIs and policies to support their development in Vietnam. First of all, the paper tries to build an analysis framework to identify aspects of the SI development to analyze. Analyses of these aspects presented in the next section may serve as a basis for the planning and policies on SI development needed for industrialization in the coming years.

\section{A FRAMEWORK FOR ANALYZING THE ROLE OF SIs}

Mori (2005) defines SIs as industries that supply manufactured inputs intermediate goods and capital goods - to other industries. In specific conditions of a country, however, SIs are determined by structure of existing industries, such as shares of industries that employ inputs from SIs in total industrial production or export. Decision 12/2011/QĐ-TTg by the Vietnamese PM on policies on SI development defines SIs as "producers of materials, spare parts, accessories, and semi-finished goods supplying them to industries that produce or assemble finished capital or consumer goods." Porter (1990) considers SIs and industrial clusters are among factors that determine competitiveness of supported industries, while Christophe et al. (2011) argue that development of an industry depend very much on background and trend of international economic integration. This implies that the role of SIs varies according to international background, or in other words, analyzing fitness of SIs requires analyses of their compatibility with international trends.

Additionally, identifying SIs also depends on production structure of the enterprise in specific countries. As quoted by Ohno (2006), Professor Takahiro Fujimoto of Tokyo University has suggested two basic architectural types in manufacturing: modular architecture and integral architecture. Their characteristics could be seen in 
Table 1. Generally speaking, modular architecture is suitable for obtaining quick results at low cost while integral architecture is appropriate for the pursuit of everhigher quality in the long run.

Table 1: Modular versus Integral Manufacturing

\begin{tabular}{|c|c|c|}
\hline & Modular manufacturing & Integral manufacturing \\
\hline Parts interface & $\begin{array}{l}\text { Parts are common and can be used for } \\
\text { any model }\end{array}$ & $\begin{array}{l}\text { Each product has unique parts, specially } \\
\text { designed }\end{array}$ \\
\hline Merits & Quick results and flexibility & Endless pursuit of quality \\
\hline Demerits & $\begin{array}{l}\text { No differentiation, excess entry, low } \\
\text { profit, lack of R\&D }\end{array}$ & $\begin{array}{l}\text { Much energy and time needed to } \\
\text { achieve results }\end{array}$ \\
\hline $\begin{array}{l}\text { Institutional } \\
\text { requirements }\end{array}$ & $\begin{array}{l}\text { Openness, quick decision making, } \\
\text { flexible outsourcing }\end{array}$ & $\begin{array}{l}\text { Long-term relations, building internal } \\
\text { skills \& knowledge }\end{array}$ \\
\hline
\end{tabular}

Source: Ohno (2006), p. 15.

Manufacturing architecture of a country depends on its technological levels. Ohno (2006) divides the industrial development of a country into four stages: stage 1, simple manufacturing under foreign guidance; stage 2, having supporting industries, but still under foreign guidance; stage 3, technology and management mastered, and being able to produce high-quality goods; and stage 4 , full capability in innovation and product design as global leader. He calls the move from stage 1 to stage 2 agglomeration; stage 2 to stage 3: technical absorption; and stage 3 to stage 4: creativity. Vietnam is trying its best to move from stage 1 to stage 2 because SI development is still in a very early phase; only initial ideas are suggested; and the SI development plan performs poorly. Better realization of the planning and developing SIs may produce high added values for goods with competitive advantages, and provide good conditions for the move to the stage of technical absorption and better integration into the regional economy. 
The aforementioned literature review shows that the planning of SI development requires analyses of various aspects: background and trends of the world industrial development; value chain of industrial production including manufacturing structure and participation in global value chain; and linkages of existing sectors (forward and backward linkages) and roles of industrial clusters/parks. Analytical results will serve as a basis for development planning and recommendations to policies on SI development by absorbing new technologies. The analytical framework is presented in Figure 1.

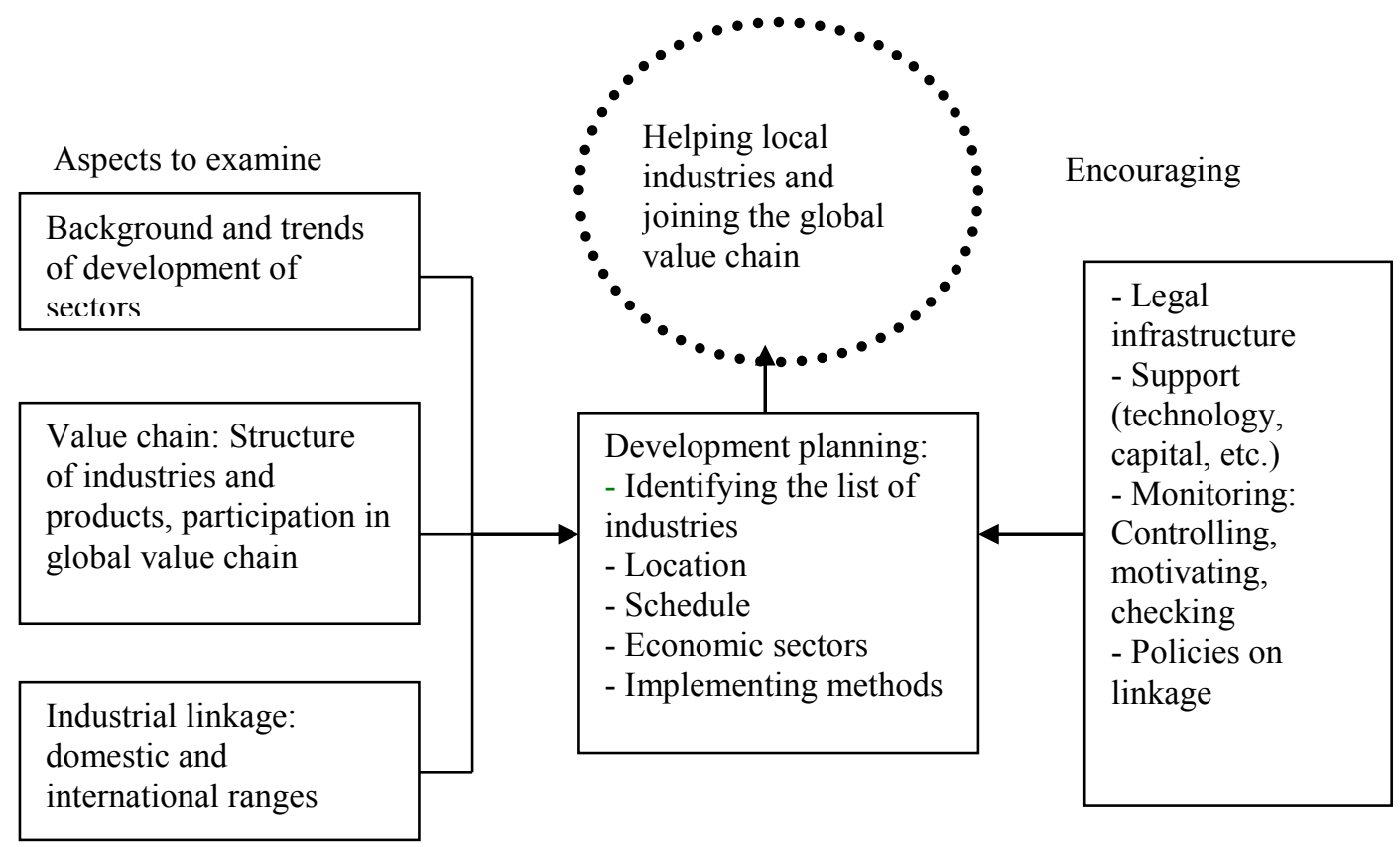

Figure 1: Analytical Framework

Source: Author's suggestion based on literature review 


\section{AN OVERVIEW ON VIETNAMESE SIS}

Vietnamese SIs have developed in recent years, but their share in industrial output is still small, increasing from $4.37 \%$ in 2000 to $7.32 \%$ in 2008 , a two-fold rise within eight years, as shown in Table 2.

Table 2: SI Share in Industrial Output

\begin{tabular}{lccc}
\hline & $\mathbf{2 0 0 0}$ & $\mathbf{2 0 0 5}$ & $\mathbf{2 0 0 8}$ \\
\hline Total & $100.00 \%$ & $100.00 \%$ & $100.00 \%$ \\
Mining industry & $15.78 \%$ & $11.19 \%$ & $9.82 \%$ \\
Manufacturing industry & $78.68 \%$ & $83.20 \%$ & $85.54 \%$ \\
+ SI & $4.37 \%$ & $6.45 \%$ & $7.32 \%$ \\
Power, gas and water & $5.54 \%$ & $5.61 \%$ & $4.63 \%$ \\
\hline
\end{tabular}

Source: GSO (2010)

The share of Vietnamese SIs in the global value chain is much smaller. Table 3 shows that in 2000-2009, the share of export from SIs did not rise, staying around $7.45 \%$ in those nine years. This implies that industrialization in Vietnam has not entered the stage of technological agglomeration, and Vietnamese SIs are still "separate" from the global value chain.

Table 3: SI Share in Export Value

\begin{tabular}{lcccc}
\hline & $\mathbf{2 0 0 0}$ & $\mathbf{2 0 0 5}$ & $\mathbf{2 0 0 8}$ & $\mathbf{2 0 0 9}$ \\
\hline Total export value & $100 \%$ & $100 \%$ & $100 \%$ & $100 \%$ \\
SI share & $7.46 \%$ & $7.59 \%$ & $7.45 \%$ & $7.45 \%$ \\
Electronic apparatuses and spare parts & $5.45 \%$ & $4.40 \%$ & $4.21 \%$ & $4.84 \%$ \\
Plastic goods & $0.66 \%$ & $1.10 \%$ & $1.49 \%$ & $1.06 \%$ \\
Electric wire and cable & $0.89 \%$ & $1.60 \%$ & $1.61 \%$ & $1.55 \%$ \\
Bicycle and spare parts & $0.46 \%$ & $0.49 \%$ & $0.14 \%$ & $0.00 \%$ \\
\hline
\end{tabular}

Source: GSO (2010). 
Table 4: Import Structure

\begin{tabular}{lcccc}
\hline & $\mathbf{2 0 0 0}$ & $\mathbf{2 0 0 5}$ & $\mathbf{2 0 0 8}$ & $\mathbf{2 0 0 9}$ \\
\hline Total & 100.0 & 100.0 & 100.0 & 100.0 \\
SI share & 93.8 & 89.6 & 88.8 & 90.2 \\
Machine, apparatus, component & 30.6 & 25.3 & 28.0 & 29.3 \\
Raw materials, fuel & 63.2 & 64.4 & 60.9 & 60.9 \\
Consumer goods & 6.2 & 8.2 & 7.8 & 9.3 \\
Non-monetary gold & & 2.2 & 3.4 & 0.5 \\
\hline
\end{tabular}

Source: GSO (2010).

Imports used for SIs, meanwhile, still accounted for $90.2 \%$ of import value in 2009 and showed no sign of decline (Table 4). This means that the local industrial production gained a very small added value and depended heavily on foreign markets.

\section{ASPECTS IDENTIFYING SIs}

\section{a. Background and Development Trends of Sectors:}

Vietnam is gradually integrating into the world economy (Võ Thanh Thu, 2010). In this process, each country becomes a component of market and global production chain (Đoàn Thị Hồng Vân, 2010). Changes in macroeconomic policies, technologies, confidence, and economic crises in some countries produce great effects on politicoeconomic environment of other countries (Christophe et al., 2011). Planning of SI development in Vietnam, therefore, requires full attention to trends of changes in global value chain with the following characteristics:

Firstly, market for manufactured consumer goods is polarized remarkably. Developed countries tend to consume final manufactured goods from technologyintensive industries; technological value is considered as a top priority and consumers support eco-friendly and good-for-health products (Kunnanatt, 2011). This implies that only a few opportunities are available for manufactured goods from developing countries to penetrate into developed markets or get through technical barriers set by developed countries to protect their consumers (Kunnanatt, 2011).

Secondly, most economies are interdependent: a manufactured commodity is divided into various stages or components and produced in many countries based on 
their comparative advantages (Cudney \& Elrod, 2011). Developed countries undertake designing and finishing the commodity (the first and last stage of production) while developing and emerging economies produce equipments, components, and control assembling lines (intermediate stages); these stages are assigned according to comparative advantages of developing countries (Kunnanatt, 2011; Cudney \& Elrod, 2011).

Thirdly, global sources of capital mainly come from developed economies that manipulate production in developing countries through business strategies of multinationals based on comparative-advantage principle to minimize production costs (Cantarello et al., 2011). This process is supported by governments of developed countries through official aid to infrastructure and financial development in developing countries (Cantarello et al., 2011).

The above facts show that division of markets and production chains is taking place at the global level based on exploiting comparative advantages of each economy. This implies that nations should position their roles in the global market and production chain. In other words, all nations should identify export markets for their staple products and their positions in the global value chain. This means more difficulty for Vietnam when its staple exports depend too much on foreign markets, its technological absorption is poor, its SIs are scattered and the global value chain has been positioned in developed economies.

\section{b. Value Chain in Vietnamese Industrial Sector:}

Industries considered as advantages for Vietnam are labor-intensive ones that employ simple technologies, exploit natural resources, and attract huge foreign direct investments (Porter et al., 2010). Its staple exports, therefore, are mainly from laborintensive and natural-resource-dependent industries (Figure 2). This is a characteristic of a manufacturing sector with simple structure, without SIs and a driving force to improve technological and managerial capacity of local firms (Ohno 2006; Mori 2005).

At present, Vietnam has no industry with a totally-internalized structure. Even in industries with high export values such as clothing and footwear, internalization ratio is still very low because imported raw materials and machinery represent huge proportions of export value (Figure 3) 


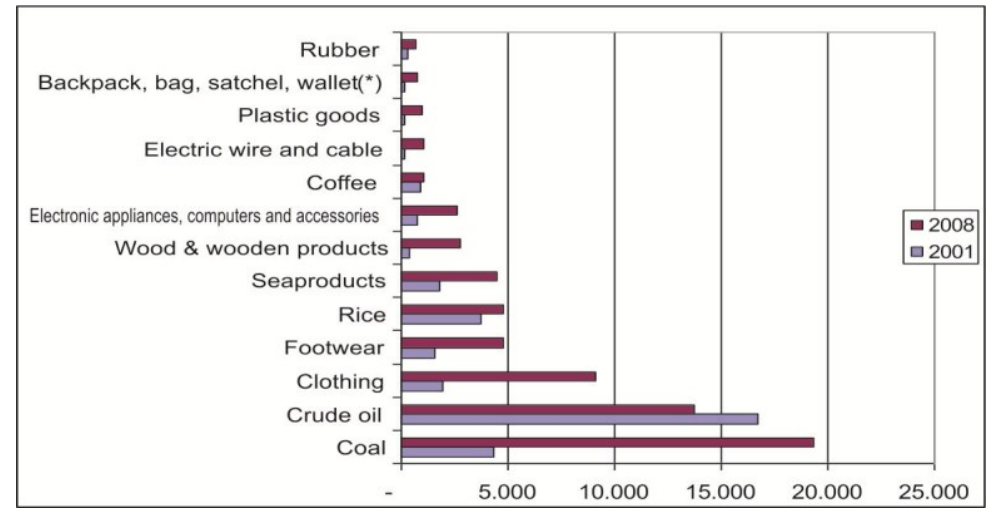

Figure 2: Vietnam's Staple Exports (US\$ MN.)

Source: GSO (2010).

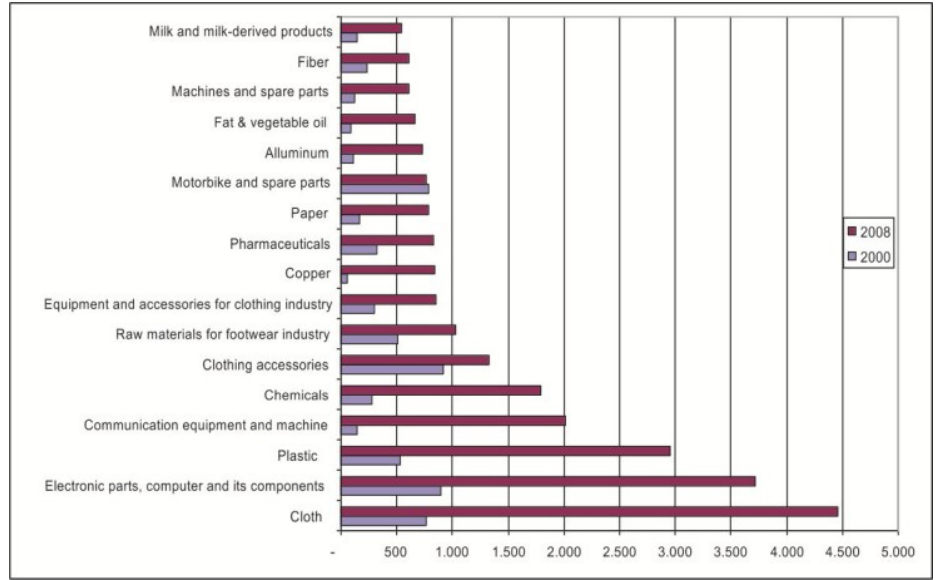

Figure 3: Vietnam's Typical Imports (US\$ MN.)

Source: Calculations based on GSO data (2010)

Moreover, Vietnam has not determined which one among its industries will join the global value chain while its production under foreign guidance has a low internalizing ability. A list of Vietnam's staple exports (Figure 2) shows that spare parts and accessories represent small quantities; and most of them are electronic components produced by FDI companies and depend on foreign markets.

\section{c. Linkages Between Industries:}

Vietnamese industries are scattered in terms of value chain and space for production. Local firms do not form a value chain for a complete industry comprising supply of inputs, production and supply of outputs. Generally, most industries rely on 
imported inputs, especially raw materials and spare parts (Figure 3). This is the reason why their production cost is high and competitiveness low.

Moreover, Vietnam's economic sectors usually operate separately, as remarked by Porter et al. (2010, p. 95), "state enterprises concentrate on capital-intensive activities such as transportation and utilities. Private enterprises focus on more short-term and service-oriented activities such as retails, hotels and restaurants, real estate, etc. FDI enterprises initially focused on import-substitution manufacturing and then gradually shifted more to export-oriented light industries and recently to real estate." Lack of linkages between economic sectors prevents technology transfer and limits access to the global value chain for local firms.

Zoning area for industrial parks and clusters is usually carried out to facilitate control over companies instead of trying to bring similar factories together to form some linkages between them. As Porter et al. (2010) put it, cluster development in Vietnam has the following features: "presence of naturally emerging agglomerations; focus on narrow industries; low level of active collaboration; economic policy tools, e.g. industrial parks, not systematically oriented towards clusters; sector-oriented policies largely driven by traditional industrial policy ideas; and poor implementation."

\section{POLICIES ON PLANNING AND PROMOTION OF SIS IN VIETNAM}

The policy on SI development has just been given some attention recently. Decision 12/2011/QĐ-TTg issued by the PM on Feb. 24, 2011 introduced some measures to develop Sis. The Decision offers encouragement to many SIs, including mechanical engineering, electronics - informatics, automobile assembling and manufacturing, clothing, footwear, and high-tech SIs. A policy encouraging participants in SI development in terms of marketing, infrastructure, technical assistance, training, information service and financial support has been also introduced.

Generally, SI development policy limits itself to a list of industries and fields provided with encouragement from the government. No specific planning for the SI development suggesting a schedule, a location and necessary measures is set forth. The new policy, after its promulgation, is not associated with plans or projects to develop or link SIs with industries producing finished goods, or identify SIs that can join the global value chain. 


\section{POLICY RECOMMENDATIONS}

\section{a. Analytical Results:}

Vietnamese SIs are very small and unable to help local production enhance its capacity, which becomes the reason why the structure of industry made no progress in the past ten years (2000-2010). Analyses of bases for planning the SI development are presented in Figure 4 with the following characteristics:

- Trend of internationally economic integration shows that two characteristics relating to positioning of SIs of a nation are division of markets, and division of the global manufacturing value chain by countries where multinationals play dominant roles and control the global manufacturing value chain. Identifying SIs, therefore, aims at not only supporting development of local industries but also obtaining a position in the global value chain. This means that planning the SI development should be based on staple products that Vietnam enjoys some comparative advantages.

- Vietnamese SIs have many limitations: Production of goods supporting local industries requires large quantities of imported materials while export from SIs cannot join the global value chain. This keeps Vietnamese industries at a simple manufacturing level. Even FDI companies engage in simple manufacturing activities or join the global value chain through their holding firms. This situation prevents local firms from getting access to new technologies and internalizing ability cannot be realized.

Infrastructure for development of industrial parks and clusters only facilitates state control over industries and fails to create linkages between local firms within a cluster or park.

SI development policy limits itself to a list of industries and fields encouraged by the government and fails to suggest a schedule, a location and implementing measures. Such policies are not associated with plans or projects to develop or link SIs with industries producing finished goods, or fail to identify SIs that can join the global value chain.

\section{b. Policy Recommendations:}

The SI development plan should pay attention to groups of SIs requiring support, participants in each group, locations for building factories, schedule of SI development, and implementing methods. 
- Planning for each SI and participants:

Planning at industry level should be based on SI importance to domestic production and its position in global value chain. Regarding participation in the global value chain, selected SIs should be the ones that produce goods easily integrated into various products. In other words, they are modular manufacturing industries. In Vietnam, such industries should be automobile parts, electronics and mechanical engineering. Participants in these industries for the time being are FDI companies. This implies that government support in terms of training, financial services, and market development is not necessary, except for a better investment climate.

Analyses of manufacturing structure of local firms show that most of them made final goods that are simple, based on imported raw materials and of low added values. The most typical are clothing and footwear industries, and therefore, SIs for such industries should be developed as soon as possible. Participants in these SIs are certainly local firms who are badly in need of government support in various aspects as mentioned by Decision 12/2011/QĐ-TTg. Main market for such SIs is the domestic one while foreign ones should have lower priority.

Development of SIs for high-tech industries requires careful plans because they are integral manufacturing industries. Because these SIs depend very much on foreign designing and completing factories, participants in these SIs are FDI companies, at least in a short run. In a longer term, new technologies may be transferred to local firms.

- Location for SI development:

SIs that join the global value chain or have an integral manufacturing structure tend to pay more attention to infrastructure conditions and supply of labor than organizational issues because their products are sold to foreign companies and their markets have been determined.

As for SIs for assemblers or producers of final goods for domestic market, the plan should identify locations for factories in vertical or horizontal linkages, including producers of raw materials and parts and components, to assemblers of finished goods. These locations may become industrial clusters or parks.

- Schedule and implementing methods: 
The SI development plan should determine a short-term plan for local firms that want to build SIs for domestic production of final goods, along with a long-term one to attract FDI companies that are able to join the global value chain. In this process, cooperation between local and FDI companies should be built to facilitate transfer of technology and social capital in order to help local firms take part in the global value chain.

\section{c. On Policies Encouraging SI Development:}

To help SIs development and serve as a driving force for domestic industries, and find a foothold in the global value chain, the government should adopt various encouraging policies:

- Building a legal infrastructure for SI development by introducing an SI development master plan that serves as a basis for similar plans at provincial/municipal level: Provinces in the same economic zone can cooperate in developing their SIs. A National SI Commission can be formed to monitor the whole process, give advices about SI planning and policies to both central and local governments.

- Examining designs of manufacturing chain in certain industries to identify supporting stages in the chain: In Vietnam up until now, making such designs have been done totally by companies. It is about time the government assumed the responsibility in some key industries to determine which stages belong to SI and include them in the SI development plan.

- Carrying out a pilot project to build an SI cluster in a province where manufacturing sector develops well: The selected province may be in Eastern South Vietnam that enjoys the highest economic growth rate. To ensure success for the pilot project, several well-managed state-owned companies can be allowed to play leading roles. Target industries may be clothing or footwear ones because they produce staple exports.

- Introducing a mechanism for promoting SI development: This support should comprise improved infrastructure, technical and financial assistance, and establishment of close linkages in the value chain. The mechanism can be realized through various programs and projects that aim at attracting more companies to SIs. 


\section{CONCLUSION}

SIs play an important role in generating added values for manufactured products. An SI development plan should be based on analyses of international background, manufacturing value chain and linkages between domestic and foreign industries. Such a plan should identify a list of SIs and their future positions in the global value chain; along with locations, schedules and methods of implementing the plan. In addition to the plan, various policies should be adopted to encourage the SI development, including policies to improve legal system, make designs of value chains for key industries, carry out a pilot project to build an SI cluster, and establish a mechanism for promoting SI development

\section{References}

Campaniaris, C. et al. (2011), "The Applicability of Cluster Theory to Canada's Small and MediumSized Apparel Companies", Journal of Fashion Marketing and Management, Vol. 15 Iss: 1, pp.8 -26 .

Cantarello, S. et al. (2011), "External Technology Sourcing: Evidence from Design-driven Innovation", Management Decision, Vol. 49 Iss: 6, pp.962 - 983.

Christophe, M. et al. (2011), "Approaches to Managing Global Sourcing Risk", Supply Chain Management: An International Journal, Vol. 16 Iss: 2, pp.67 - 81.

Cudney, E. \& C. Elrod (2011), "A Comparative Analysis of Integrating Lean Concepts into Supply Chain Management in Manufacturing and Service Industries", International Journal of Lean Six Sigma, Vol. 2 Iss: 1, pp.5 - 22.

Đoàn Thị Hồng Vân (2010), "Một số giải pháp tái cấu trúc thị trường xuất nhập khẩu” in Kỉ yếu hộ thảo khoa học: Phuc hồi, thúc đẩy tăng truởng và kiểm soát lạm phát sau suy giảm kinh tế tại $V N$ (Proceedings of Seminar "Promoting Economic Growth and Controlling Inflation after a Period of Recession in Vietnam") held by University of Economics HCMC, pp. 165-175.

Kunnanatt, J.T. (2011), "Global Business Chain and Twin Advantage: Strategic Opportunities for Developing Countries", Competitiveness Review: An International Business Journal Incorporating, Journal of Global Competitiveness, Vol. 21 Iss: 4, pp.352 - 368.

Li, L. \& G. Vinten (1997), "An Overview of the Experiences of Chinese Industrialization Strategies and Development", Managerial Auditing Journal, Vol. 12 Iss: 4/5, pp.183 - 191.

Marktanner, M., \& J. Nasr (2009), "Potentials of Democratization, Demilitarization, Industrialization, and Contraception", Journal of Economic Studies, Vol. 36 Iss: 3, pp.236 - 249. 
Mori, J. (2005), Development of Supporting Industries for Vietnam's Industrialization: Increasing Positive Vertical Externalities Through Collaborative Training, Master of Arts in Law and Diplomacy Thesis, The Fletcher School.

Ohno K., (2006), Hoạch định chính sách công nghiệp ở Thái Lan, Malaysia và Nhạt: Bài học kinh nghiệm cho các nhà hoạch định chính sách VN, (translation of Industrial Policy Formulation in Thailand, Malaysia and Japan: Lessons for Vietnamese Policy Makers), Lao động xã hội Publisher, Hà Nội.

Ohno, K., (2007), "Building Supporting Industries in Vietnam", Vietnam Development Forum (VDF), Vol 1.

Porter, M.E, \& Vietnam's Central Institute for Economic Management (2010), Báo cáo đánh giá năng lực cạnh tranh của quốc gia của VN (Vietnamese version of Vietnam Competitiveness Report 2010 by Michael E. Porter), Hà Nội.

Porter, M.E., (1990), The Competitive Advantage of Nations, Free Press, New York.

GSO (2010), Niên giám thống kê VN (Vietnam's Statistical Yearbook) retrieved from http://www.gso.gov.vn on Aug. 8, 2011.

Võ Thanh Thu (2010), "Bàn về giải pháp giảm nhập siêu ở VN hiện nay", in Kỉ yếu hội thảo khoa họ: Phục hồi, thúc đẩy tăng trưởng và kiểm soát lạm phát sau suy giảm kinh tế tại VN (Proceedings of seminar "Promoting Economic Growth and Controlling Inflation after a Period of Recession in Vietnam") held by University of Economics HCMC, pp.155-164. 